\title{
ARTYKUŁ RECENZYJNY
}

„Studia Wyborcze”, tom 31, 2021

DOI: https://doi.org/10.26485/SW/2021/31/1

\section{Grzegorz Kuca*}

(iD) https://orcid.org/0000-0001-8713-3241

\section{LAT „STUDIÓW WYBORCZYCH”}

Konieczność utworzenia interdyscyplinarnej platformy wymiany wiedzy i doświadczeń w zakresie szeroko pojętej problematyki wyborczej i referendalnej staje się nieodzownym elementem badań naukowych nad stanem współczesnej demokracji. Dowodzą tego różnego rodzaju definicje demokracji formułowane przez przedstawicieli nauk prawnych, politologicznych, socjologicznych czy ekonomicznych, których cechą wspólną pozostaje bezpośredni związek z wyborami. Wystarczy przywołać słynną definicję A. Przeworskiego, który stwierdza, że demokracja to „system, w którym partie polityczne przegrywają wybory”. Dalej A. Przeworski uznaje, że ,demokracja to system rozładowywania konfliktów, zaś rezultaty funkcjonowania tego systemu zależą od tego, co robią jego uczestnicy, ale to co w nim się wydarzy, nie jest uzależnione od jednego, dominującego czynnika" [1998, t. 2: 119, 120]. O ile jednak związek wyborów z demokracją nie budzi wątpliwości, o tyle nie ma zgody odnośnie tego, co ostatecznie przesądza o tym, czy wybory są demokratyczne lub niedemokratyczne, innymi słowy, czy przeprowadzane są w warunkach demokracji liberalnej lub nieliberalnej ${ }^{1}$, która - według zapewnień A. Przeworskiego - ,jest nieliberalna, ponieważ politycy spodziewają się, że inaczej przegraliby wybory”.

Na tym tle formułowane jest pytanie pozostające w pewnej mierze bez odpowiedzi, czy rozstrzygające znaczenie przypisać należy wypracowanym wzorcom normatywnym stającym się po ich utrwaleniu standardem międzynarodowym,

* Dr hab., prof. UJ, Katedra Prawa Ustrojowego Porównawczego oraz Centrum Interdyscyplinarnych Studiów Konstytucyjnych, Wydział Prawa i Administracji, Uniwersytet Jagielloński, g.kuca@uj.edu.pl

${ }^{1}$ Pojęcie to opracował i spopularyzował F. Zakaria [1997: 22 i in.]. 
czy praktyce ich urzeczywistnienia odbiegającej niekiedy znacznie od przyjętych rozwiązań prawnych ${ }^{2}$. Doskonałym tego przykładem jest ewolucyjnie ukształtowany katalog zasad prawa wyborczego, będący katalogiem otwartym, stopniowo utrwalanym i regularnie poddawanym presji. W takich warunkach kształtują się zasady: powszechności w przeciwieństwie do ograniczeń tworzonych przez cenzusy, równości w przeciwieństwie do uprzywilejowania jednych kosztem dyskryminacji drugich, bezpośredniości w przeciwieństwie do wyborów dwustopniowych, polegających na wyborcze elektorów decydujących w imieniu wyborców o personalnej obsadzie organu wybieranego, czy wreszcie tajności, w przeciwieństwie do jawności, dającej możliwość zapoznania się z treścią oddanego przez wyborców głosu. Świadomi tego stanu rzeczy politycy sprawujący władzę, przewidując, że mogą przegrać wybory, podejmują rozmaite działania polegające $\mathrm{z}$ jednej strony na zmianie reguł wyborczych, z drugiej strony na rozszerzeniu kompetencji władzy wykonawczej kosztem pozostałych władz, w szczególności władzy sądowniczej.

Zarysowana, z natury rzeczy skrótowo, potrzeba prowadzenia badań naukowych nad problematyką prawa wyborczego była z pewnością jednym z decydujących argumentów branych pod uwagę przez silny ośrodek łódzkich konstytucjonalistów na czele z prof. Krzysztofem Skotnickim przy utworzeniu w 2006 roku pierwszego w Polsce czasopisma naukowego poświęconego problematyce wyborczej. Czasopismo to otrzymało zręcznie dobrany i łatwo zapadający w pamięć tytuł „Studia Wyborcze”. Od samego początku jego wydawcą jest Łódzkie Towarzystwo Naukowe. W tym miejscu należy podkreślić, że wcześniejszy brak czasopisma ukierunkowanego na problematykę wyborczą był aż zanadto odczuwany, szczególnie że zainteresowanie tą problematyką utrzymywane jest stale na wysokim poziomie. Najlepszym tego dowodem pozostaje liczba pozycji monograficznych, wieloautorskich prac zbiorowych, artykułów i innych publikacji naukowych dotyczących wyborów i referendów, a ponadto żywa dyskusja środowisk politycznych przy okazji formułowania propozycji reform lub przeprowadzania konkretnych już zmian w prawie wyborczym [Uziębło 2015: 105-106].

$\mathrm{Z}$ pewnością drugim argumentem uzasadniającym potrzebę zorganizowania kolejnego forum współpracy środowiska naukowego było, stopniowo i konsekwentnie, rozszerzanie materii prawa konstytucyjnego prowadzące do wyo-

\footnotetext{
${ }^{2}$ Bodaj najlepszym tego przykładem są zarządzone przez Marszałek Sejmu w drodze postanowienia wydanego na podstawie Konstytucji RP z 1997 r. i Kodeksu wyborczego z 2011 r. i nieprzeprowadzone wybory prezydenckie w Polsce. Sytuacja ta wymusiła na PKW podjęcie uchwały o tym, że brak możliwości głosowania na kandydatów był równoważny w skutkach z sytuacją braku kandydatów, Zob. uchwała nr 129/2020 Państwowej Komisji Wyborczej z 10.05.2020 r. w sprawie stwierdzenia braku możliwości głosowania na kandydatów w wyborach Prezydenta Rzeczypospolitej Polskiej; www.pkw.gov.pl (dostęp 20.01.2021).
} 
drębnienia swego rodzaju podgałęzi prawa wyborczego [Chruściak 2011: 114], która wraz z uchwaleniem Kodeksu wyborczego z 5 stycznia 2011 roku, stanowiącego kwalifikowaną formę porządkowania przepisów prawnych, polegającą na całościowym, względnie wyczerpującym i opartym na jednolitych zasadach uregulowaniu jakiejś dziedziny życia społecznego [Sarnecki 1996: 93; Skotnicki 2011: 11 i n.], stopniowo przekształca się w gałąź prawa. Uzasadnia to potrzebę zagospodarowania odrębnej i względnie zamkniętej, bo rządzącej się swoimi regułami, przestrzeni wymiany poglądów. Jest tak, tym bardziej że zakres i sposób uregulowania zagadnień wyborczych w konstytucjach państw współczesnych jest relatywnie wąski, a towarzyszący temu szeroki zakres unormowania ustawowego (wystarczy wspomnieć o tym, że Kodeks wyborczy liczy aż 517 artykułów, do tego dochodzą dwa załączniki oraz szereg aktów wykonawczych) uzupełniany przez akty wewnętrzne, które wpływają na ostateczne rozumienie przepisów prawa wyborczego, niejako optymalizując, z zastosowaniem reguł wykładni, system źródeł prawa wyborczego ${ }^{3}$.

$\mathrm{Na}$ marginesie należy wspomnieć, że rozwijaniu tej przestrzeni sprzyja także powołane do życia w 2008 roku Centrum Studiów Wyborczych jako jednostka organizacyjna Wydziału Prawa i Administracji Uniwersytetu Łódzkiego, które prowadzi działalność edukacyjną, szkoleniową i badawczą w zakresie szeroko pojętej problematyki wyborczej i referendalnej we współpracy z Centrum Studiów Wyborczych na Wydziale Prawa i Administracji Uniwersytetu Mikołaja Kopernika w Toruniu oraz Państwową Komisją Wyborczą i Krajowym Biurem Wyborczym.

Zaszczytną funkcję redaktora naczelnego „Studiów Wyborczych” przez cały okres ich funkcjonowania pełni prof. Krzysztof Skotnicki, kierownik Katedry Prawa Konstytucyjnego WPIA UŁ i prezes Polskiego Towarzystwa Prawa Konstytucyjnego, którego merytorycznie wspiera prof. Anna Rakowska-Trela pełniąca funkcję zastępcy redaktora naczelnego, zaś organizacyjnie mgr Magdalena Wrzalik - sekretarz redakcji. Do tego dochodzi rozbudowana i wielonarodowa rada redakcyjna, której skład na przestrzeni lat ulegał zmianie, obecnie tworzą go: Andrzej Antoszewski (Polska), Olena Boryslawska (Ukraina), Marek Domin (Słowacja), Timea Drinóczi (Węgry), Jiři Jírasek (Czechy), Grzegorz Kryszeń (Polska), Tomasz Milej (Kenia), Angelika Nußberger (Niemcy), Ladislav Orosz (Słowacja), Magdalena Pietrzak (Polska), Wiktor Rudenko (Rosja), Andrzej Sokala (Polska), Oksana Szczerbaniuk (Ukraina),

${ }^{3}$ Tytułem ilustracji można wskazać wykładnię art. 9 § 2 Kodeksu wyborczego w związku ze śmiercią jednego z kandydatów w wyborach do Senatu w 2019 r. Zob. opinia A. Rakowskiej-Treli opublikowana na stronie internetowej www.konstytucyjny.pl, https://konstytucyjny.pl/anna-rakowska-trela-m-komorowski-nie-mogl-juz-zostac-zgloszony-za-w-miejsce-zmarlego-k-morawieckiego/ (dostęp 20.01.2021). 
Haroldas Szinkunas (Litwa), Andrzej Szmyt (Polska), Miruna Tudorascu (Rumunia), Piotr Uziębło (Polska), Jacek Wojnicki (Polska), Arkadiusz Żukowski (Polska).

Udział w powstawaniu czasopisma przypada też pokaźnej rzeszy recenzentów, których liczba w zależności od stopnia zróżnicowania prezentowanych treści waha się od jednego (np. tom 11) przez siedmioro (tom 14), aż do dziesięciorga (tom 30). Jeśli chodzi o grono recenzentów to warto odnotować, że za każdym razem były to osoby o ugruntowanej pozycji naukowej, często podejmujące w swojej pracy zagadnienia podlegające ocenie. Co się zaś tyczy autorów publikujących w „Studiach Wyborczych” to pozostają nimi nie tylko polscy naukowcy, ale znaczna część tekstów nadsyłana jest przez naukowców z zagranicy (głównie państw Europy Środkowej i Wschodniej). Taka konwencja pozwala czytelnikowi spojrzeć na polskie prawo wyborcze i praktykę wyborów $\mathrm{z}$ uwzględnieniem specyfiki regionu, w tym podobieństw i różnic występujących w innych państwach, zwłaszcza te drugie wnoszą do badań naukowych istotny czynnik heurystyczny pozwalający na wypracowanie optymalnych (modelowych) rozwiązań prawnych.

Każdy z 30. regularnie, dwa razy do roku, publikowanych tomów otrzymał atrakcyjną i konsekwentnie stosowaną szatę graficzną w stonowanej i skromnej kolorystyce niebielonego lnu z marmurowym akcentem na grzbiecie, z wyraźnie wyeksponowanym tytułem czasopisma, numerem tomu, rokiem wydania, wykazem artykułów i nazwą wydawcy (projekt okładki - Agnieszka Roman). Czasopismo otrzymało stabilną i dostosowaną do jego zawartości merytorycznej strukturę, na którą składa się kilka wyodrębnianych tytułów tworzących stałe lub występujące cyklicznie działy: Studia i artykuty, Recenzje, Sprawozdania, Wyniki wyborów i referendów na świecie, Glosy, Bibliografia, pojawiają się także Raporty czy Ttumaczenia. Ważnym elementem budowania pozycji „Studiów Wyborczych” jest praktyka zamieszczania wersji elektronicznej treści w nich zawartych na stronie internetowej: www.czasopisma.ltn.lodz.pl/Studia-Wyborcze oraz w bazach: CEJSH, CEEOL, Index Copernicus, a także ich indeksacja w wielu kluczowych bazach danych: Index Copernicus (ICV: 201986.16; 2018-78.93; 2017-83.86), PBN/POL-Index, CEEOL, EBSCOhost, CEJSH, Proquest, ERIH Plus, CrossRef (DOI).

Najważniejszym i zarazem najbardziej podstawowym dla czasopisma naukowego działem są Studia i artykuły. W każdym numerze "Studiów Wyborczych" znajduje się od pięciu do sześciu artykułów, z tą jednak różnicą, że w najnowszych tomach liczba ta bywa nieznacznie wyższa, np. w tomie 25 . było dziewięć artykułów, a w tomie 30. - siedem. Świadczy to z jednej strony o coraz większym zainteresowaniu środowiska naukowego możliwością prezentacji swoich wyników badań, a z drugiej strony o potencjalnej możliwości wpływu tych wyników na otoczenie społeczne. Docenić też należy coraz 
częstszą obecność przedstawicieli nauk obcych. We wskazanym tomie 30 . było to aż ośmioro badaczy reprezentujących ośrodki naukowe z Czech, Kenii, Serbii, Słowacji, Rumunii, Węgier.

Jednak to, co w największym stopniu dywersyfikuje czasopisma naukowe, to poziom prezentowanych $w$ nim wyników badań. $Z$ tego punktu widzenia należy stwierdzić, że o ile w pierwszym okresie działalności „Studiów Wyborczych" zdarzały się artykuły o charakterze deskryptywnym mające raczej charakter poznawczy, o tyle wraz z upływem czasu coraz częściej publikowane są teksty samodzielne, oryginalne czy nawet przełomowe, których charakter jest w pełni tego słowa naukowy. Na korzyść półrocznika wpływa też coraz mocniejsze akcentowanie wątków komparatystycznych, zwłaszcza że głównym problemem współczesnego prawa wyborczego nie jest wynalezienie czegoś całkowicie nowego, a raczej wykorzystanie osiągnięć współczesnych państw demokratycznych i wyprowadzeniu tych osiągnięć poza granice tych państw; nowa jest tylko forma, jaką ten proces przyjmie. Miarą wartości czasopisma naukowego jest też żywiołowość dyskusji naukowej podejmowanej pod wpływem publikowanych treści. $Z$ tego punktu widzenia warto wskazać, że niektóre z artykułów doczekały się polemik, co świadczy o sporym zainteresowaniu ich treścią. Tytułem przykładu $\mathrm{w}$ tomie 23. pojawił się tekst polemiczny na temat wyników liderów list wyborczych [Rakowski 2012: 61-77].

W początkowym okresie działalności „Studiów Wyborczych” relatywnie rzadko pojawiał się dział Glosy, który w ostatnich latach występuje znacznie częściej. Na tym polu aktywność wykazuje zastępca red. naczelnego - prof. A. Rakowska-Trela, która nie tylko z racji pełnionej funkcji, ale też z zamiłowania do wykonywania zawodu adwokata jest autorką połowy z dotychczas opublikowanych glos. W tomie 5. opublikowano glosę dotyczącą postanowienia Sądu Najwyższego z 1 października 2007 roku (sygn. akt III SW 7/07) odnoszącą się do kwestii odrzucenia przez Państwową Komisję Wyborczą sprawozdań finansowych dwóch partii politycznych [Sułkowski 2008: 119-126], w tomie 14. - do postanowienia Sądu Najwyższego z 10 listopada 2011 roku dotyczącą powołania komitetu wyborczego w wyborach do Senatu [Rakowska-Trela 2014: 99-108], w tomie 19. - do wyroku Trybunału Konstytucyjnego z 23 stycznia 2014 roku traktującą o instytucji wygaśnięcia mandatu wójta (burmistrza, prezydenta miasta) [Kurowski 2015: 127-135], w tomie 22. - do wyroku Trybunału Konstytucyjnego z 6 kwietnia 2016 roku (sygn. akt P 5/14) dotyczącą uprawnień właściwego komisarza wyborczego w zastępstwie organów gminy, w tym do podziału gminy na okręgi wyborcze [Rakowska-Trela 2016: 105-113].

Relatywnie mała liczba glos nie wynika raczej ze skromnego dorobku orzeczniczego polskich sądów i Trybunału Konstytucyjnego w sprawach wyborczych. Wystarczy tylko wspomnieć o wyroku Trybunału Konstytucyjnego z 20 lipca 2011 roku (sygn. K 9/11) dotyczącego oceny zgodności z Konstytucja 
$R P$ z 1997 roku przepisów Kodeksu wyborczego z 2011 roku, czy postanowieniu Sądu Rejonowego w Nowym Sączu z 19 kwietnia 2019 roku (sygn. akt I Ns 376/19) nakazującego dopisanie do spisu wyborców wyborcy częściowo ubezwłasnowolnionego, czy postanowieniu Sądu Okręgowego w Krakowie z 26 października 2018 roku (sygn. akt I Ns 41/18) oraz postanowieniu Sądu Apelacyjnego w Krakowie z 30 października 2018 roku (sygn. akt I ACz 1433/18). Moim zdaniem każde ze wskazanych wyżej orzeczeń mogłoby stanowić podstawę do przygotowania, a niektóre $\mathrm{z}$ nich nawet różnego nurtu (aprobujących i krytycznych) glos. Warto zatem rozważyć, czy dział Glosy powinien częściej gościć w „Studiach Wyborczych”, zwłaszcza gdy uwzględnić liczne i zróżnicowane orzecznictwo zagranicznych organów, w tym sądów, trybunałów orzekających w sprawach wyborczych. Glosowanie tych orzeczeń z pewnością wpłynęłoby na zwiększenie liczby czytelników, a w dalszej perspektywie na pozycję czasopisma na rynku wydawniczym.

Regularnie pojawia się dział Recenzje. W pierwszych piętnastu tomach występuje on w trzynastu (z wyjątkiem: 8., 10., 16.), a od tomu 16. w ośmiu (z wyjątkiem: 16., 20., 23., 24., 26., 28., 30.) tomach. Na ogół w tym dziale występuje recenzja jednej pozycji, choć zdarzały się tomy (np. 22), że były to dwie (w tym jedna dotycząca pozycji anglojęzycznej). Obok oczywistego waloru informacyjnego (prezentacja i charakterystyka nowych pozycji literatury), recenzje pełnią istotną funkcję ocenną, a przez to kształtują gust czytelnika, zaś ewentualne refleksje krytyczne, nadające im formę artykułu recenzyjnego, mogą stanowić inspirację do weryfikacji lub rozwijania stawianych tez, a być może nawet sformułowanie nowych problemów badawczych. Warto zatem zadbać, aby ten dział na stałe zagościł na łamach „Studiów Wyborczych”, co z oczywistych powodów wymusiłoby konieczność podjęcia się trudu recenzji publikacji zagranicznych.

Użytecznym poznawczo działem są Sprawozdania występujące w tomach: $1-4,10-11,13,15-18,20,23,25,27,29$. Dotyczą one na ogół konferencji naukowych, nie tylko krajowych, ale też zagranicznych, np. w tomie 20. [Rulka 2015: 93-98], w tym także spotkań roboczych służących podjęciu konkretnych działań, np. w tomie 4. zawierającym omówienie spotkania eksperckiej grupy doradczej opracowującej pierwszy ogólnoświatowy podręcznik o rozstrzygnięciu sporów wyborczych [Chludziński, Complak 2007: 135-140]. Z natury rzeczy możliwość publikacji w tym dziale skierowana jest do środowiska młodych naukowców, którzy, rozpoczynając pracę naukową, mają okazję do zapoznania się z warsztatem pisarskim i nabycia wymaganych umiejętności do rozpoczęcia badań naukowych w pełnym tego słowa znaczeniu.

Relatywnie rzadko pojawiały się działy: Raporty oraz Ttumaczenia. Tytułem przykładu w pierwszym w nich występującym w tomie 8. przedstawiono streszczenie wraz z komentarzem tekstów opublikowanych w tygodniu powyborczym (po wyborach w 2007 r.) na łamach najważniejszych dzienników o zasięgu 
ogólnokrajowym [Hołub 2009: 149-154], w drugim, uwzględnionym m.in. w tomach 7. [Sułkowski 2009: 101-109] oraz 24. [Rulka 2012: 97-105] opublikowano przekład na język polski orzeczeń odpowiednio węgierskiego Sądu Konstytucyjnego oraz australijskiego Sądu Najwyższego. Zdarzyło się także, niezmiernie rzadko spotykane, thumaczenie zdania odrębnego, autorstwa K. Complaka [2008: 155-165], do uchwały Centralnej Rady Wyborczej Dominikany.

Jako załącznik do tomu 10. opublikowana została polska bibliografia poświęcona problematyce wyborczej i referendalnej, która obejmowała publikacje wydane w latach 1989-2010. Jednocześnie zapowiedziano, że w kolejnych latach bibliografia będzie regularnie ukazywać się w poszczególnych tomach oznaczonych liczbą parzystą i będzie zawierała wykaz prac publikowanych powstałych w poprzednim roku kalendarzowym. Zgodnie z tą zapowiedzią uruchomiony został nowy konsekwentnie prowadzony dział nazwany Bibliografia zawierający wykaz opublikowanej literatury wyborczo-referendalnej [za dany rok].

Jednym ze stałych pojawiających się w każdym z 30. tomów „Studiów Wyborczych" jest dział Wyniki wyborów i referendów na świecie prezentujący jak sama nazwa wskazuje - zebrane i opracowane w formie tabelarycznej wyniki wyborów prezydenckich, parlamentarnych i referendów przeprowadzonych w ściśle wskazanych okresach roku (na ogół od 1.10. do 31.03. oraz od 1.04. do 30.09.) wraz z powołaniem źródła ich pochodzenia i innych przydatnych informacji uzupełniających. Taka konwencja ma istotny walor poznawczy i pozwala badaczom podejmującym problematykę wyborczą na łatwy dostęp do bazy źródłowej stanowiącej podstawę dalszych analiz.

Od samego początku „Studia Wyborcze” nastawione są na podejmowanie i prowadzenie dyskusji naukowej odpowiadającej interdyscyplinarności ${ }^{4}$ polegającej na dominacji trzech dyscyplin naukowych, tj. nauk: prawnych, politologicznych, socjologicznych, dzięki czemu możliwa jest ocena społeczeństwa i zachodzących w nim procesów z różnych perspektyw, a nadto zbadanie poszczególnych zagadnień z pomocą rozmaitych metod badawczych. Symptomatyczne, że wiele wątków prawnych podejmowali politolodzy, a niektóre wątki politologiczne prawnicy. Bez wątpienia na pierwszym miejscu akcentowane jest ujęcie prawnicze polegające na wyjaśnieniu i ocenie zasad i procedur prawa wyborczego, w tym aspektu teoretycznego polegającego na próbach konceptualizacji pojęć z zakresu prawa wyborczego (np. w tomie 19. opublikowano istotny tekst dotyczący mieszanych systemów wyborczych [Michalak 2015: 7-30]), aspektu konstytucyjnego: (np. w tomie 21. wart uwagi artykuł na temat uczciwości jako zasady prawa wyborczego [Kryszeń 2018: 7-30], a w tomie 22. zawarto niebywale inspirujący artykuł dotyczący wpływu judicialization of politics na prawo wyborcze [Bień-Kacała 2018: 5-15]), aspektu europejskiego (np. w tomie 5. znajduje się instruktywny komentarz

\footnotetext{
${ }^{4}$ Ciekawe rozważania na ten temat prezentuje A. Olechno [2016: 117-126].
} 
dotyczący ordynacji wyborczej do Parlamentu Europejskiego [Składowski 2008: 35-42], a w tomie 20. - ważny głos w dyskusji naukowej na temat wadliwości podziału na okręgi wyborcze do Parlamentu Europejskiego [Michalak 2010: 7-26]), aspektu karnistycznego (np. w tomie 2. zaprezentowano poglądy na temat przestępstw przeciwko wyborom i referendom [Jurewicz 2006: 27-38], a w tomie 19. - rozważania dotyczące przestępczości wyborczej w Niemczech [Wąsik 2015: 107-125]).

$\mathrm{Na}$ drugim miejscu sytuowane są wątki politologiczne, w tym ustalenie w jaki sposób polityka i aktorzy polityczni wpływają na procesy wyborcze, a nadto jaką rolę odrywają $\mathrm{w}$ tych procesach partie polityczne i inni aktorzy sceny politycznej (np. w tomie 7. znajdują ciekawe rozważania na temat nowych dróg głosowania i ich wpływu na aktywność wyborców [Filip 2009: 7-24], w tomie 13. - zachęcający do dyskusji tekst dotyczący personalnych aspektów rywalizacji wyborczej [Peszyński 2012: 33-48]). Trzecie miejsce przypada wątkom socjologicznym, w tym spadek zaufania społecznego do wyborów i przemiany społeczne towarzyszące tym procesom, a także reakcje społeczeństwa na jej skutki (np. w tomie 22. znajduje się artykuł analizujący postawy Polaków wobec prawa wyborczego i mechanizmów kampanii wyborczej [Roguska, Zbieranek 2011: 47-68]). Do wyjątków nadal jednak należą teksty komparatystyczne w pełnym tego słowa znaczeniu (np. w tomie 8. znajduje się ciekawy tekst o progach wyborczych w ujęciu porównawczym [Rulka 2009: 23-66], a w tomie 18. systemowe opracowanie dotyczące przedterminowych wyborów parlamentarnych [Antoszewski 2014: 7-26] oraz poruszające zagadnienia ekonomiczne, zwłaszcza że wybory i kampania wyborcza wymagają ogromnych środków finansowych przeznaczonych na ich finansowanie. Jeśli chodzi o zagadnienia ekonomiczne to warto wskazać, że jednym z głównych nurtów światowych badań pozostaje poszukiwanie odpowiedzi na pytanie, w jaki sposób prawo wyborcze, terminy wyborów, orientacja polityczna i ideologiczna oraz natura konkurencji politycznej wpływają na politykę fiskalną i monetarną [Alesina, Roubini, Cohen 1997: 1 i n.].

Mając na uwadze potrzebę internacjonalizacji wyników polskich badań naukowych, które - w moim przekonaniu - swoim poziomem w niczym nie ustępują wynikom zagranicznych badań, a także umiędzynarodowienie rady redakcyjnej reprezentującej - obok polskich badaczy - dziewięciu przedstawicieli różnych państw regionu, a w końcu last but not least spore zainteresowanie możliwością publikacji autorów zagranicznych warto rozważyć regularne wydawanie „Studiów Wyborczych" w języku angielskim. W tym miejscu należy dodać, że począwszy od 1982 roku wydawane jest czasopismo „Electoral Studies”, co sugerowałoby potrzebę doboru innego anglojęzycznego tytułu ${ }^{5}$. Można by w nich

\footnotetext{
${ }^{5}$ http://www.journals.elsevier.com/electoral-studies/ (dostęp 28.01.2021).
} 
publikować (np. raz na dwa lata) tłumaczenia najważniejszych lub najciekawszych tekstów wcześniej wydanych bądź całkiem nowych po raz pierwszy prezentowanych i zasługujących na popularyzację poza granicami naszego kraju. Oczywiście autor tych słów zdaje sobie sprawę, że nie jest to zadanie łatwe, ale z pewnością możliwe do wykonania.

Konkludując, można jednoznacznie stwierdzić, że idea utworzenia, konsekwentnego prowadzenia i stałego rozwijania „Studiów Wyborczych” stanowi nieoceniony wkład w rozwój prawa wyborczego. Od samego początku półrocznik pozostaje niewyczerpanym źródłem wiedzy o prawie wyborczym, systemach wyborczych i referendach oraz praktycznych aspektach funkcjonowania określonych rozwiązań w Polsce i na świecie. Trudno wyobrazić sobie poważne opracowanie problematyki wyborczej i referendalnej bez uwzględnienia treści w nim zawartych. Wszystkim osobom, które przez 15. lat angażowały lub angażują się w budowanie marki „Studiów Wyborczych” należą się słowa uznania, wyrazy wdzięczności i najserdeczniejsze gratulacje.

\section{BIBLIOGRAFIA}

Alesina Alberto, Roubini Nouriel, Cohen Gerald D. 1997. Political Cycles and the Macroeconomy. Cambridge: Cambridge University Press.

Antoszewski Andrzej. 2014. „Przedterminowe wybory parlamentarne w Europie Środkowej i Wschodniej. Model normatywny, przyczyny i konsekwencje”. Studia Wyborcze 17.

Bień-Kacała Agnieszka. 2018. „Polski przypadek judicialization of politics. Wpływ na prawo wyborcze". Studia Wyborcze 25.

Chludziński Bartłomiej, Complak Krystian. 2007. „Spotkanie eksperckiej grupy doradczej opracowującej pierwszy ogólnoświatowy podręcznik o rozstrzygnięciu sporów wyborczych, Sztokholm, 17-18 września 2007 roku”. Studia Wyborcze 4.

Chruściak Ryszard. 2011. „Uwagi recenzyjne na tle dziesięciu tomów Studiów Wyborczych (2006-2010)". Studia Wyborcze 11.

Complak Krystian. 2008. „Zdanie odrębne M.A. Rodrígueza Rijo do uchwały Centralnej Rady Wyborczej Dominikany z 7.04.2008 r.”. Studia Wyborcze 6.

Filip Jan. 2009. „W poszukiwaniu nowych dróg dla głosowania i ich wpływ na aktywność wyborców". Studia Wyborcze 7.

Hołub Adam. 2009. „Wybory 2007 - tydzień powyborczy na łamach najważniejszych dzienników o zasięgu ogólnokrajowym (raport)". Studia Wyborcze 8.

Jurewicz Justyna. 2006. „Przestępstwa przeciwko wyborom i referendom z rozdziału XXXI Kodeksu karnego". Studia Wyborcze 2.

Kryszeń Grzegorz. 2018. „Uczciwość wyborów jako zasada prawa wyborczego”. Studia Wyborcze 21.

Kurowski Krzysztof. 2015. „Glosa do wyroku Trybunału Konstytucyjnego z dnia 23 stycznia 2014 r., sygn. akt K 51/12”. Studia Wyborcze 19.

Michalak Bartłomiej. 2010. „Dlaczego obecny model podziału na okręgi wyborcze do Parlamentu Europejskiego w Polsce jest wadliwy i czy jest dla niego alternatywa?" Studia Wyborcze 20 . 
Michalak Bartłomiej. 2015. „Mieszane systemy wyborcze: hybryda czy nowa rodzina systemów wyborczych?" Studia Wyborcze 19.

Olechno Artur. 2016. „Multidyscyplinarność Studiów Wyborczych”. Studia Wyborcze 21.

Peszyński Wojciech. 2012. „Personalne aspekty rywalizacji wyborczej do Sejmu Rzeczypospolitej Polskiej. Analiza zjawiska ,jeżdżenia na gapę” na wybranych przykładach”. Studia Wyborcze 13.

Przeworski Adam. 1998. Demokracja i rynek. W Władza i społeczeństwo. Antologia tekstów z zakresu socjologii polityki. Red. J. Szczupaczyński. Tom 2. Warszawa: Scholar.

Przeworski Adam. 2019. Crises of Democracy. Cambridge: Cambridge University Press.

Rakowska-Trela Anna. 2014. „Glosa do postanowienia Sądu Najwyższego z 10 listopada 2011 r., sygn. akt III SW 102/11”. Studia Wyborcze 14.

Rakowska-Trela Anna. 2016. „Glosa do wyroku Trybunału Konstytucyjnego z 6 kwietnia 2016 r. w sprawie sygn. akt P 5/14". Studia Wyborcze 22.

Rakowski Maciej. 2012. „Lokomotywy czy odkurzacze? - O wynikach liderów list wyborczych. Polemika z Wojciechem Peszyńskim”. Studia Wyborcze 13.

Roguska Beata, Zbieranek Jarosław. 2011. „Polacy o prawie wyborczym i mechanizmach kampanii. Badania przed wyborami parlamentarnymi 2011 roku”. Studia Wyborcze 11.

Rulka Marcin. 2009. „Progi wyborcze - analiza prawnoporównawcza”. Studia Wyborcze 8.

Rulka Marcin. 2012. „Australia: orzeczenie Sądu Najwyższego z dnia 30 sierpnia 2007 r. w sprawie prawa do głosowania więźniów (sygn. HCA 43)”. Studia Wyborcze 13.

Rulka Marcin. 2015. „Sprawozdanie z Międzynarodowej Konferencji Naukowej (Conference for e-Democracy and open Government), Krems (Austria), 20-22 maja 2015 roku”. Studia Wyborcze 20.

Sarnecki Paweł. 1996. „O pojęciu „kodeks” i procedurze rozstrzygania o jego zakresie oraz w sprawie trybu nowelizacji kodeksów”. Przegląd Sejmowy 2

Składowski Konrad. 2008. „Ordynacja do Parlamentu Europejskiego (kilka uwag de lege ferenda)". Studia Wyborcze 5.

Skotnicki Krzysztof. 2011. Przebieg prac nad kodeksem wyborczym. W Kodeks wyborczy. Wstepna ocena. Red. K. Skotnicki. Warszawa: Wydawnictwo Sejmowe.

Sułkowski Jarosław. 2008. „Glosa do postanowienia Sądu Najwyższego z 1 października 2007 r. (sygn. akt III SW 7/07) w przedmiocie odrzucenia przez Państwową Komisję Wyborczą". Studia Wyborcze 5.

Sułkowski Jarosław. 2009. „Wyrok Sądu Konstytucyjnego Republiki Węgierskiej w sprawie konstytucyjności ciszy wyborczej oraz ośmiodniowego zakazu publikacji przedwyborczych sondaży opinii publicznej (sygn. 6/2007 (II. 27.) AB)". Studia Wyborcze 7.

Uziębło Piotr. 2015. „Problemy prawa wyborczego w publikacjach Studiów Wyborczych”. Studia Wyborcze 20.

Wąsik Damian. 2015. „Przestępczość wyborcza w Republice Federalnej Niemiec - model ochrony prawnokarnej wyborów, charakter zjawiska i skala zagrożenia”. Studia Wyborcze 19.

Zakaria Fareed. 1997. „The Rise of Illiberal Democracy”. Foreign Affairs 6 (76).

\section{ŹRÓDŁA INTERNETOWE}

http://www.journals.elsevier.com/electoral-studies/ (dostęp 28.01.2021).

https://konstytucyjny.pl/anna-rakowska-trela-m-komorowski-nie-mogl-juz-zostac-zgloszony-

za-w-miejsce-zmarlego-k-morawieckiego/ (dostęp 20.01.2021).

https://www.pkw.gov.pl 